\title{
Grain Exports and Inflation
}

\author{
CLIFTON B, LUTTRELL
}

P RIVATE grain exporters have notified the United States Department of Agriculture (USDA) of their intentions to sell more than 10 million tons of grain to the Russians in the current marketing year. The sales include 177 million bushels of corn, 154 million bushels of wheat, and 50.5 million bushels of barley. ${ }^{1}$ They constitute about 3,7 , and 13 percent, respectively, of the prospective corn, wheat, and barley crops and are equivalent to 13,18 , and 84 percent, respectively, of our average annual exports of these crops to all foreign purchasers for the past five years.

The grain sales to Russia this year are for cash. They carry neither a Government price subsidy nor a Government credit arrangement. Payments for the shipments will be made with funds which can be used immediately to purchase goods and services from abroad.

This is in contrast to the 1972 sales which involved substantial Government subsidies. The U.S. Government at that time maintained a subsidy on all wheat sold in foreign markets. The subsidy kept the international price for U.S. wheat at a lower level than the domestic price. These subsidies were a holdover from the old farm programs which were designed to reduce the domestic grain supply and increase domestic grain prices. In addition to the price subsidies, the Russians received a subsidized credit of $\$ 750$ million that was made available over a three-year period for purchasing the grain.

This year, however, no export subsidies on wheat are available and no subsidized credit is granted to the purchaser. Consequently, most of the basic economic arguments against the 1972 transactions are missing.

Nevertheless, the recent sales to Russia, like the earlier sales, have received considerable criticism. Some analysts have argued that the exports will contribute to higher food prices and to inflation. ${ }^{2}$ The rising prices of grain and soybeans during recent weeks are pointed to as evidence of the inflationary effects of the sales. Higher grain and soybean prices

士The Wall Street Journal, July 24, 1975.

"For examples of such views, see "Russia Feeds U.S. Inflation," Business "Week, August 11, 1975, pp. 14-15; "Prices: A Rude Surprise," Time Magazine, August 4, 1975; p, 59; and Robert E. Grant, "Mr. Butz and the Grain Sales to Russia," The Wall Street Journal, July 28, 1975. contribute to higher meat and poultry prices which, in turn, are believed to spill over into higher prices for industrial raw materials. Hence, restrictions on grain exports have been proposed in order to halt this asserted inflationary impact.

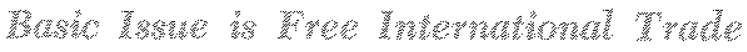

In the controversy over the entry of Russia into the domestic grain market, one major point has been largely overlooked. Restrictions on grain exports to the Russians will not prevent domestic grain prices from rising unless restrictions are placed on all grain exports. If, for example, the Russians purchased grain exclusively from Canada, prices there and in other world trading centers would rise and U.S. grain dealers would have the incentive to sell in those markets. Grain markets are international and prices in these markets reflect international supply and demand conditions. Grain will flow to those locations where the price is highest so long as the price differential exceeds transportation costs. Thus, as long as the United States ships grain freely to any other nation, sales to Russia by U.S. dealers will have no more of an impact on domestic grain prices than the same amount of sales by the Canadian Grain Commission or by Australian dealers. Consequently, preventing a rise in domestic grain prices involves the imposition of comprehensive controls on grain exports to all nations.

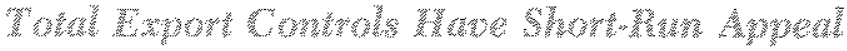

Comprehensive export controls could be used in the short run to limit the quantity of grain exports, reduce domestic grain prices, and raise world grain prices. The Organization of Petroleum Exporting Countries (OPEC) is an example of an action where a minimum price has been set on petroleum exports. This has led to the accumulation of a surplus of oil in member countries since the rest of the world has not been willing to purchase all the oil produced by the cartel at the prevailing fixed prices. The effect on the quantity and price of goods exported is the same whether the action is initiated by export controls or by artificial price supports.

Some nations, by imposing such controls, are able to increase their wealth since in the short run the gains from higher prices more than offset the decline 
in the quantity of their exports. The OPEC members have received more foreign exchange for a smaller amount of exported oil than formerly.

It does not appear that American wheat farmers are in the same position as OPEC. While it may be true that total world grain consumption does not fall sharply in response to higher prices, the United States faces strong competition from other grain producing nations. If we were to limit, through export controls, the amount of grain we make available in the world market, the effect would certainly be a somewhat higher world price than otherwise would be the case, since the United States supplies a major portion of the world's grain exports. But our restrictions would cause other grain producing countries to increase their exports. Our competitors, instead of American grain farmers, would surely gain. Small wonder, then, that grain farmers are objecting vociferously to proposals to restrict grain exports - domestic grain prices will almost certainly be lower than world grain prices.

Historically, popular and political demands for intemational trade restrictions generally have been for limitations on imports, through the imposition of either tariffs or quotas. These restrictions have penalized consumers who have been forced to pay higher prices for protected goods in order to benefit producers who could not compete effectively in a free market. In contrast, export restrictions initially hurt producers by depriving them of access to free world markets, and help consumers by increasing the domestic supply. However, over the longer run it is not simply a case of helping one group at the expense of another. Accepted economic theory implies that, in general, trade restrictions make this country as well as the entire world less well off.

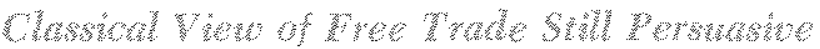

Despite some occasional short-run gains from international trade restrictions, the classical view of international exchange remains persuasive. In 1776 Adam Smith outlined a system of free trade among nations with arguments which are still held as valid by most economic analysts. ${ }^{3} \mathrm{He}$ pointed to the gains from the specialization of labor and trade in a small community. Through such specialization and exchange of goods and services the total volume of real product is increased and the costs of goods and services are lower than if each person attempted to be selfsufficient.

adam Smith, The Wealth of Nations (New York; The Modem Library, 1937), pp. 3-4.
Smith postulated that the gains accruing from the specialization of labor and other resources in a local economy are not basically different from those accruing from the specialization of resource use and exchange among nations. ${ }^{4} \mathrm{He}$ contended that the benefits stem directly from imports rather than from exports. Gains accrue because the imported commodities can be acquired through trade at a lower cost than similar or substitutable commodities can be produced domestically.

The mutual gains from trade can be demonstrated with a simple example using only two countries and two goods. Suppose we consider some hypothetical cost of production figures for the United States and West Germany, as in Table I.

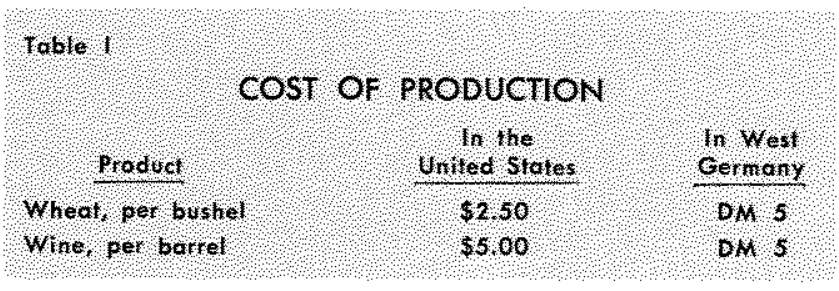

In the United States, we must devote to the production of every barrel of wine resources which could otherwise produce two bushels of wheat, while West Germany gives up only one bushel per barrel of wine. Alternatively, we can say that the United States gets two bushels of wheat for every barrel of wine we give up in production, while West Germany gets only one. Clearly, the U.S. is a more efficient (that is, lower cost) producer of wheat, and West Germany is a more efficient producer of wine.

Suppose with an exchange rate of 1.5 Deutschmarks per dollar, we decide to export 100 bushels of wheat for which we give up potential production of 50 barrels of wine. In order to get the $\$ 250$ to pay for the wheat, West Germany gives us DM 375 (1.5 x $\$ 250$ ) which we in turn can use to buy 75 barrels of wine, surely an improvement over the 50 we gave up. Notice also that Germany's DM 375, which purchased 100 bushels of wheat in the United States, would have yielded only 75 bushels of domestically produced wheat.

This example shows that countries engaging in trade are able to get more goods and services from their endowments of resources than they could by using those resources to produce solely for their own consumption. Each is encouraged to expand the production of those goods which it produces more efficiently and to trade them for goods which others can produce

Ibid, p. 424. 
at lower cost. Conversely, any restriction which turns a country back toward greater self-sufficiency attains it at the cost of getting less from its resources - that is, a lower standard of living.

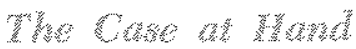

Considering the nation as a whole, what might we expect to result from the imposition of restrictions on the amount of grain exported? Given an inelastic demand for grain, a small decline in U.S. grain exports could cause a relatively large increase in the world price of grain in the short run. Total receipts derived from grain exports would then be greater than in the absence of export restrictions. Depending on the extent to which U.S. farmers participate in the higher returns from the world grain market, both farmers and consumers could gain relative to the free market solution. On the other hand, if the world price of grain did not rise sufficiently to offset the reduced volume of grain exports (that is, if demand for grain is elastic), total receipts derived from these sales would be less than without the grain export limitations. The dollar price of foreign currency would then be higher, resulting in higher prices paid for the foreign goods and services we import. In this case the farmer is obviously worse off and the consumer is either better or worse off, depending on one's purchases of domestic food relative to imported goods and services. So even immediately, the restrictions which lead to lower domestic grain prices might not provide an unmixed blessing for American consumers.

In the longer run, however, the effects of export restrictions are more drastic (and we have learned how difficult it is to escape from "temporary" government policies, once they are established). Grain farmers, finding that they are not allowed to garner the profits which they would receive from free trade as a result of their superior efficiency as compared to their foreign competitors, will reduce grain production and turn to alternative forms of employment. In short, resources which were previously used to pro. duce goods which we could sell to other countries in exchange for commodities which they produce more cheaply are now used to produce those commodities for ourselves - at a higher cost.

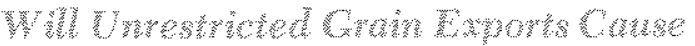

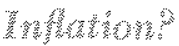

The belief that inflationary pressures arise from the unrestricted export of grain stems from a basic confusion between the forces which cause changes in relative prices and those which affect the general price level. It is quite true that an increase in foreign demand, if it is allowed to be effective, would raise the price of grain and grain-related products. It is not true, however, that this effect would spill over to higher prices for other goods. The increased demand for dollars to buy the grain would make imported goods and services less costly to Americans - if not now, then at some time in the future. This, in turn, would exert a downward pressure on the prices of domestic goods which compete with imports. Further, the higher price of dollars to foreigners would induce them to buy fewer American goods, leaving more available for domestic consumption and making them cheaper to us.

On the other hand, a rise in the price level (that is, a rise in the average of prices of all goods) occurs when we have more money to spend on an unchanged stock of goods and services or if we were to have the same amount of money to spend on a smaller quantity. This would certainly occur if we were to give our grain away, receiving nothing in return. Since this is not the question in the recent grain sales, there is no reason to expect that allowing farmers to sell their output as profitably as they can will contribute to inflation.

It is far more likely that a higher price level will follow from a long-run policy of export restriction on farm products. The resultant shift of resources out of agriculture into other uses implies that we will have fewer of all goods and services than we could otherwise have. Without reduced money supply growth and with a smaller commodity bundle available for domestic purchase, aggravated inflation is to be expected.

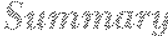

Export controls on grain shipments to Russia have been proposed. It is contended that such exports lead to higher food prices and further inflation. Restrictions on exports to Russia, however, will not prevent domestic grain prices from rising unless comprehensive controls are placed on all grain exports.

Comprehensive export controls have appeal in the short run since they tend to restrict current domestic food prices. In the longer run the effects of export controls are always harmful. They result in a decline in the world value of the dollar, an increase in the price of imported goods, less output from our productive resources, a higher average price level, and a lower standard of living. 